\title{
EFFECTS OF THE ENVIRONMENT AND SPATIAL FACTORS ON THE REGENERATION OF ARAUCARIA FOREST FRAGMENTS, SOUTHERN BRAZIL
}

\author{
DUARTE, S. W. $.^{*}-$ HOFFMANN, L. T. ${ }^{1}-$ MAÇANEIRO, J. P. ${ }^{2}-$ FENILLI, T. A. B. ${ }^{1}-$ \\ SCHORN, L. A. ${ }^{1}$ \\ ${ }^{I}$ Departamento de Engenharia Florestal, Universidade Regional de Blumenau \\ Box. 89030-000 Blumenau, Brazil \\ ${ }^{2}$ Departamento de Engenharia Florestal, Universidade Federal do Paraná \\ Box. 80210-170 Curitiba, Brazil \\ ${ }^{*}$ Corresponding author \\ e-mail: swduarte0@gmail.com; phone: +55-47-3221-6043 \\ (Received $30^{\text {th }}$ Nov 2018; accepted $27^{\text {th }}$ Feb 2019)
}

\begin{abstract}
The floristic patterns of the Atlantic Forest can be explained by different environmental factors. However, recent studies have pointed to the influence of spatial factors on the structure of forest communities. In this study, we evaluated whether environmental and spatial variables influence the distribution of regenerative species in the Araucaria forest in Southern Brazil. We analyzed the vegetation in 20 circular plots with $2.5 \mathrm{~m}$ radius each. The environmental variables open-canopy and $\mathrm{Ca} / \mathrm{K}$ content of soil were the most important predictors of floristic variations in the study area, explaining $9 \%$ of the species distribution, while the pure spatial structure explained $7 \%$ of the community structure. Although much of the floristic variation remained unexplained (75\%), the results indicated the complex effect of environmental and spatial variables on the regeneration patterns of the Araucaria Forest in Southern Brazil.
\end{abstract}

Keywords: spatial structure, environmental factors, subtropical rainforest, soil-vegetation, RDA

\section{Introduction}

The Atlantic Forest domain is a global hotspot for the conservation of biodiversity and covers approximately $1,300,000 \mathrm{~km}^{2}$ of the Brazilian territory. These forests are characterized by different forest types/subdomains, being distributed along the Brazilian coast and occurring more pronounced in the Southeast and South regions (Rocha and Silva, 2013). These forests have a high species richness and a high value of endemism when compared to other Brazilian domains, however, due to a historical process of deforestation and human occupation, the Atlantic Forest is currently fragmented, presenting only $11.7 \%$ of its original coverage (Ribeiro et al., 2011). In the State of Santa Catarina, Southern of Brazil, the Atlantic Forest involves different forest types, of which the Araucaria forest stands out, with the Brazilian pine (Araucaria angustifolia) as the characteristic element (Bertol.) Kuntze), with emphasis on other species of the families Lauraceae and Meliaceae (Kersten et al., 2015). In general, the distribution of this forest type is associated with intrinsic soil, geomorphological and climatic conditions, as well as being influenced by extreme environmental factors (i.e., storms, frost, fires) (IBGE, 2012; Higuchi et al., 2016; Souza et al., 2017).

In recent years, the Araucaria forest regeneration has been the subject of several ecological studies, and the analysis of vegetation related to environmental factors has helped answer some questions about the distribution of tree species in environmental 
gradients (Higuchi et al., 2016). Among the environmental factors that affect the distribution of the regeneration of the Araucaria Forest, we highlight luminosity, opencanopy, elevation, pedological and geomorphological characteristics, among others (Higuchi et al., 2015). Although environmental factors are widely known as promoters of the Atlantic Forest distribution, little attention has been paid to spatial factors, which are important and may influence the distribution of plant species in subtropical forests (Maçaneiro et al., 2016a).

The spatial factors can be connected to biotic/stochastic processes, such as dispersion, pollination and competition (Diniz-Filho et al., 2012; Peña-Claros et al., 2012; Lewis et al., 2014). Due to the difficulty in measuring these data, spatial factors are generally neglected in vegetation studies, however, the inclusion of the spatial structure is fundamental, because it assists in the identification of important environmental processes, the variability of species in different locations, environmental heterogeneity and the effect of abiotic processes (Lewis et al., 2014). For example, environmental factors such as luminosity affect the dynamics and establishment of forest regeneration (Peixoto et al., 2012; Horn et al., 2015), while soil and topography are related to the distribution of species in environmental gradients (Dubuis et al., 2012; Baldeck et al., 2013; Mélo et al., 2013; Maçaneiro et al., 2016a). On the other hand, the spatial structure of the community directly influences the colonization and evolution of the species, becoming a fundamental mechanism in the distribution of vegetation in subtropical forests (Urbanetz et al., 2003; Baldeck et al., 2013; Neuschulz et al., 2016).

Thus, the development of studies related to natural regeneration as a function of the analysis of environmental and spatial variables becomes essential to explain the processes that control the establishment and distribution of regenerating species in the Araucaria Forest of Southern Brazil. In this sense, in the present study we analyze two main questions: (1) Which environmental factors influence the distribution patterns of regenerative species? We expect to find a great effect of soil and canopy opening in determining floristic composition, because these are well known to be the main factors conditioning changes in the composition of vegetation in the Atlantic Rainforest at local scales (Higuchi et al., 2015, 2016; Souza et al., 2017; Maçaneiro et al., 2019). (2) Is the spatial structure of the community related to regenerative species and environmental factors? We expect to find a significant effect of space, because recent studies have indicated that inclusion of the spatial component in the analysis of vegetation patterns helps in the identification of ecological processes (Maçaneiro et al., 2016a; Loebens et al., 2018). Thus, the spatial component may be important to determine the distribution of species regeneration in Atlantic Rainforest in Southern Brazil.

\section{Material and Methods}

\section{Study area}

The present study was carried out in forest fragments of the company Florestal Gateados, located in the municipality of Campo Belo do Sul, State of Santa Catarina, Southern Brazil (Figure 1). The property is located in the Pelotas river basin and in the Campos de Lages region. It is part of the RPPN Emilio Einsfeld Filho, which has a total area of $6,328.60$ ha and elevation varying from 620 to 980 meters a.s.1. $\left(27^{\circ} 55^{\prime}\right.$ and $28^{\circ} 05^{\prime} \mathrm{S}-50^{\circ} 55^{\prime}$ and $50^{\circ} 45^{\prime} \mathrm{W}$ ).

The climate of the study region, according to the Köppen classification, is of the type $\mathrm{Cfb}$ - humid mesothermic temperate climate with mild summer, and with average 
annual temperature ranging from 12 to $16^{\circ} \mathrm{C}$, average annual total rainfall of 1,600 to $1,900 \mathrm{~mm}$ and relative humidity of 78 to $80 \%$ (Alvares et al., 2013). The geology of the region is formed by the São Bento Group, which is composed of the Serra Geral Formation, which is constituted mainly by intrusions of basalts, diabase and acid lavas (Santa Catarina, 1986). The predominant soils formed by these types of rocks in the study area are Litholic Neosol, Haplic Cambisol and Nitosols (Santos et al., 2018).

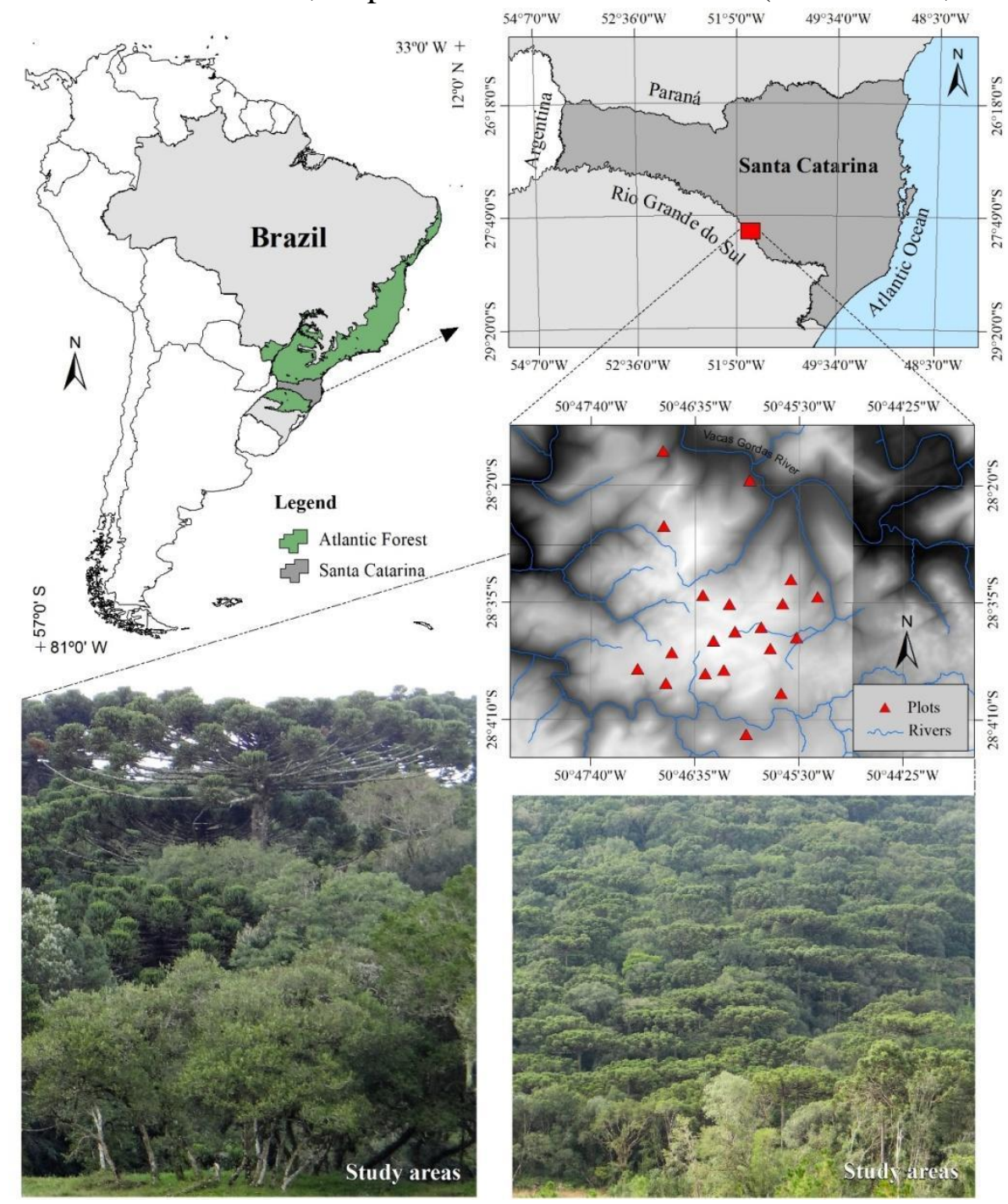

Figure 1. Studied area at RPPN Emílio Einsfeld Filho, Santa Catarina State, Southern Brazil, and the distribution of the sample plots

The vegetation of the studied area is constituted by the Araucaria Forest (Mixed Needle-Broadleaved Forest - Oliveira-Filho, 2015). This vegetation is characterized by the presence of dense clusters formed by Araucaria angustifolia and associated with several tree and shrub species of the Myrtaceae and Lauraceae families (Kersten et al., 2015). Currently, the vegetation in the study area is in advanced stage of regeneration, with about 35 years without anthropic exploration (Maçaneiro et al., 2018). 


\section{Data collection}

For data collection we installed 20 plots of 2.5 meters radius, in which we sampled all regenerating individuals with diameter at breast height $(\mathrm{DBH})<15 \mathrm{~cm}$ and with a minimum height of $50 \mathrm{~cm}$. We collected the data between December/2015 and April/2016. We identified the collected botanical material by comparison with exsicates deposited in the Herbarium Dr. Roberto Miguel Klein and by consulting the taxonomic literature and the specialists of the Universidade Regional de Blumenau (FURB) and the Universidade do Estado de Santa Catarina (UDESC). We used the species classification system proposed by APG IV (2016) and PPG I (2016).

To obtain the chemical properties of the soil, in each plot we collected soil samples in the depth of 0-20 $\mathrm{cm}$. Then, we stored the samples in plastic bags and sent to the Laboratory of Soil Analysis of EPAGRI (Empresa de Pesquisa Agropecuária e Extensão Rural de Santa Catarina) to obtain the chemical variables: clay content (\%), phosphorus $(\mathrm{P})$, potassium $(\mathrm{K})$, organic matter $(\%)$, aluminum $(\mathrm{Al})$, calcium $(\mathrm{Ca})$, magnesium $(\mathrm{Mg})$ and cation exchange $(\mathrm{CTC})$, aluminum saturation $(\mathrm{m} \%)$ and base saturation (V\%) and $\mathrm{pH}$ (Santos et al., 2018).

To obtain the physical properties of the soil, we collected samples with volumetric rings of the Kopecky type of known volume, i.e. we collected two points per plot. After these collections, we stored and weighed the samples for later drying in a drying kiln $\left(105^{\circ} \mathrm{C}\right)$. The moisture parameters $(\%)$ of these samples were determined by the volumetric method and soil density $\left(\mathrm{g} . \mathrm{cm}^{-3}\right)$ according to Teixeira et al. (2017). Then, to verify the influence of the canopy opening and the luminous intensity on the natural regeneration, for each site, six hemispherical photographs were taken $10 \mathrm{~m}$ apart (see Pinagé et al., 2013). We use a Nikon D3100 digital SLR camera and Nikon Fish-eye Nikkor $10.5 \mathrm{~mm}$ lens (Figure 2). The photos were analyzed in the software CAN_EYE v6.3.8 to obtain the values of canopy opening and leaf area (Weiss and Baret, 2010). We measured the luminosity index with the aid of a digital luximetro, in the center of each subplot and in the open field (Suganuma et al., 2008).
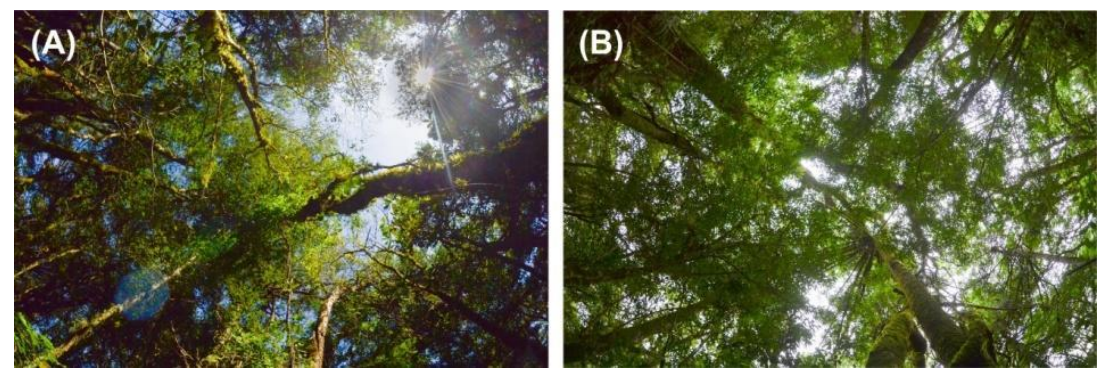

Figure 2. Hemispherical photography captured inside regeneration plots of the Araucaria Forest with high (A) and low (B) canopy opening, Southern Brazil

\section{Data analysis}

We analyzed the influence of environmental and spatial variables on regenerating vegetation through canonical analysis of RDA (Borcard et al., 2011; Legendre and Legendre, 2012). We removed collinear environmental variables through principal component analysis (PCA) in PC-ORD 6.0 (McCune and Mefford, 2011). After this procedure, the environmental variables that remained in the analysis were elevation, soil humidity $(\%)$, canopy opening $(\%)$, leaf area $\left(\mathrm{m}^{2}\right)$, luminosity $(\%), \mathrm{pH}-\mathrm{H}_{2} \mathrm{O}, \mathrm{SMP}$ 
index, base saturation (V\%), sum of bases (S), clay content (\%), potassium (K), aluminum $(\mathrm{Al})$, calcium $(\mathrm{Ca})$, magnesium $(\mathrm{Mg})$, potential acidity $(\mathrm{H}+\mathrm{Al}), \mathrm{CTC}$ at $\mathrm{pH}$ 7.0, $\mathrm{Na}$ at $\mathrm{CTC}$ and $\mathrm{Ca} / \mathrm{K}$ and $\mathrm{Mg} / \mathrm{K}$ ratios in soil.

In the abundance matrix of individuals, we removed the species that presented only one individual in the sample, since these contribute little to the data set and may hinder vegetation analysis (Legendre and Legendre, 2012). After this procedure, we applied the 'standardized score' transformation in the environmental variables, to correct the differences between the units of measure. We used the geographical coordinates (latitude and longitude) of the plots to create spatial variables called MEMs (Moran's Eigenvector Maps) in the $\mathrm{R}$ Environment using the "spacemakeR" package, as recommended by Borcard et al. (2011). We made the selection of the significant MEMs by means of the "forward" method and we also selected the environmental variables by another RDA. Finally, we processed the last RDA in PC-ORD 6.0 (McCune and Mefford, 2011), using abundance matrices with environmental (standardized) and spatial variables (MEMs) selected to verify the effect of these variables on species composition in the area of study. We verified the statistical significance of the ordering axes of the RDAs through 999 Monte Carlo permutations (Legendre and Legendre, 2012).

Then, we effected the partitioning of the variance into the data set in order to separate the fractions relative to the environment [a], the spatially structured environment [b], only the space [c] and the undetermined variables [d]. In this analysis, we used the "vegan", "packfor", "spacemakeR" and "spdep" packages in the R Environment.

\section{Results}

In the study area we sampled 466 individuals $\left(11,867\right.$ ind.ha $\left.^{-1}\right)$ belonging to 60 species and 24 botanical families (Table 1). The species in the regenerative stratum with the highest density and frequency were Allophylus edulis (A. St.-Hil.) Radlk., Myrsine umbellata Mart., Casearia decandra Jacq. and Matayba elaeagnoides Radlk. $(D R=39.1 \%$ and $F R=26.3 \%)$.

Table 1. List of the 15 species with the highest density and frequency values in the natural regeneration of the Araucaria forest in Southern Brazil

\begin{tabular}{c|c|c|c|c|c}
\hline Species & Abbreviation & DA & DR & $\boldsymbol{F A}$ & $\boldsymbol{F R}$ \\
\hline Allophylus edulis (A.St.-Hil. et al.) Hieron. ex Niederl & All edu & 1,732 & 14.6 & 65.0 & 7.6 \\
Myrsine umbellata Mart. & Myr umb & 1,197 & 10.1 & 55.0 & 6.4 \\
Casearia decandra Jacq. & Cas dec & 917 & 7.7 & 45.0 & 5.3 \\
Matayba elaeagnoides Radlk. & Mat ela & 789 & 6.7 & 60.0 & 7.0 \\
Eugenia sp. & Eug sp. & 738 & 6.2 & 40.0 & 4.7 \\
Sebastiania brasiliensis Spreng. & Seb bra & 688 & 5.8 & 25.0 & 2.9 \\
Allophylus guaraniticus (A. St.-Hil.) Radlk. & All gua & 637 & 5.4 & 40.0 & 4.7 \\
Miconia cinerascens Miq. & Mic cin & 509 & 4.3 & 10.0 & 1.2 \\
Annona emarginata (Schltdl.) H.Rainer & Ann ema & 484 & 4.1 & 25.0 & 2.9 \\
Cinnamodendron dinisii Schwacke & Cin din & 382 & 3.2 & 35.0 & 4.1 \\
Rudgea parquioides (Cham.) Müll.Arg & Rud par & 357 & 3.0 & 30.0 & 3.5 \\
Araucaria angustifolia (Bertol.) Kuntze & Ara ang & 331 & 2.8 & 35.0 & 4.1 \\
Eugenia uniflora L. & Eug uni & 306 & 2.6 & 30.0 & 3.5 \\
Styrax leprosus Hook. et Arn. & Sty lep & 255 & 2.1 & 25.0 & 2.9 \\
Brunfelsia pilosa Plowman & Bru pil & 229 & 1.9 & 20.0 & 2.3 \\
Other species & - & 2,317 & 19.5 & 315.0 & 36.8 \\
\hline
\end{tabular}

$\mathrm{DA}=$ absolute density $\left(\right.$ ind.ha $\left.^{-1}\right), \mathrm{DR}=$ relative density $(\%), \mathrm{FA}=$ absolute frequency $(\%), \mathrm{FR}=$ relative frequency $(\%)$ 
In the redundancy analysis (RDA), the plots differed according to the variation in environmental and spatial variables. The eigenvalues of the first two ordering axes explained $36.1 \%$ of the data variance (axis $1=23.4 \%$, axis $2=12.7 \%$ ) and presented significance by the Monte Carlo test $(p \leq 0.05)$. The environmental and spatial variables that correlated with axis 1 were $\mathrm{Ca} / \mathrm{K}$, MEM 3 and MEM 17, while for axis 2 only the degree of canopy opening (Figure 3, Table 2).
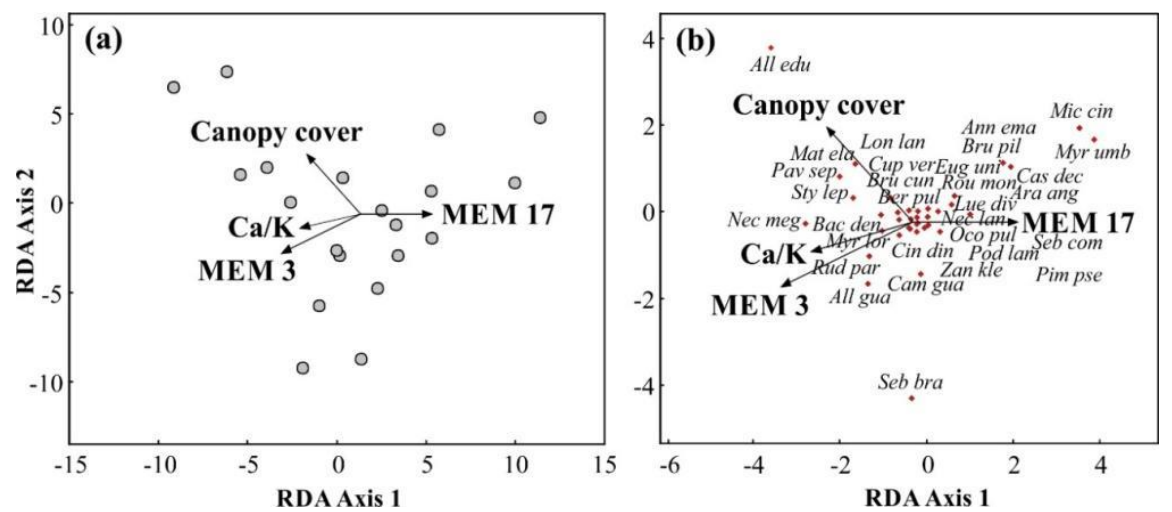

Figure 3. Redundancy analyzes (RDA) produced by plots, species and environmental and spatial variables for the Araucaria forest regeneration in Southern Brazil

Table 2. Environmental and spatial variables produced by the RDA for Araucaria forest regeneration in southern Brazil. $R^{2}$ adjusted, $F$ and $p$ were obtained by ANOVA after partitioning of the variance

\begin{tabular}{c|c|c|c|c}
\hline Predictor & Average value & $\boldsymbol{R}^{\mathbf{2}}$ adjusted (\%) & $\boldsymbol{F}$ (ANOVA) & $\boldsymbol{p}$ (ANOVA) \\
\hline MEM 3 & - & 11.0 & 3.4 & 0.001 \\
Ca/K & 13.7 & 10.4 & 3.3 & 0.009 \\
Canopy opening & 17.9 & 7.6 & 2.6 & 0.01 \\
MEM 17 & - & 4.4 & 1.9 & 0.03 \\
\hline
\end{tabular}

In the ordination diagram of the plots, we verified that the first two axes had a strong relation between canopy opening and the spatial variable MEM 17 (Table 2). The axes formed two groups of plots, the first one being related to light intensity in the environment and the second, to the spatial structure of the community. In addition, we observed the formation of a short gradient related to the $\mathrm{Ca} / \mathrm{K}$ content (Figure $3 a$ ).

In the diagram of species ordination, we verified a strong association with the canopy opening and the density of regenerating individuals of Allophylus edulis, Matayba elaeagnoides, Muellera campestris, Cupania vernalis, Brunfelsia cuneifolia, Pavonia sepium (Figure 3b), while in closed canopy sites (generally located below the broad canopies of Araucaria angustifolia) we found other predominant species (e.g., Campomanesia guaviroba, Zanthoxylum kleinii, Cinnamodendron dinisii and Sebastiania brasiliensis). Also, we observed in Figure $1 b$ an association between variables MEM 17 and $\mathrm{Ca} / \mathrm{K}$. In this case, certain species occurred in soils with high index of $\mathrm{Ca} / \mathrm{K}$ (e.g., Nectandra megapotamica, Baccharis dentata, Rudgea parquioides and Allophylus guaraniticus). On the other hand, species like Casearia decandra, Araucaria angustifolia and Ocotea pulchra are usually associated to soils with less Calcium and Potassium index, but they are positively influenced by spatial component MEM 17. 
Partitioning of variance revealed that fractions [a] "pure" environment $(F=2.071$, $p=0.008)$ and $[\mathrm{c}]$ "pure" space $(F=1.773, p=0.02)$ were significant (Figure 4$)$. The fraction $[b]$, related to space + environment, indicated that part of the analyzed environmental variables $(9 \%)$ is structured in space, while the [a] "pure" environment $(9 \%)$ and [c] "pure" space $(7 \%)$ stood out among fractions. However, the fraction [d] relative to the undetermined variables explained most of the vegetation variation in the study area $(75 \%)$.

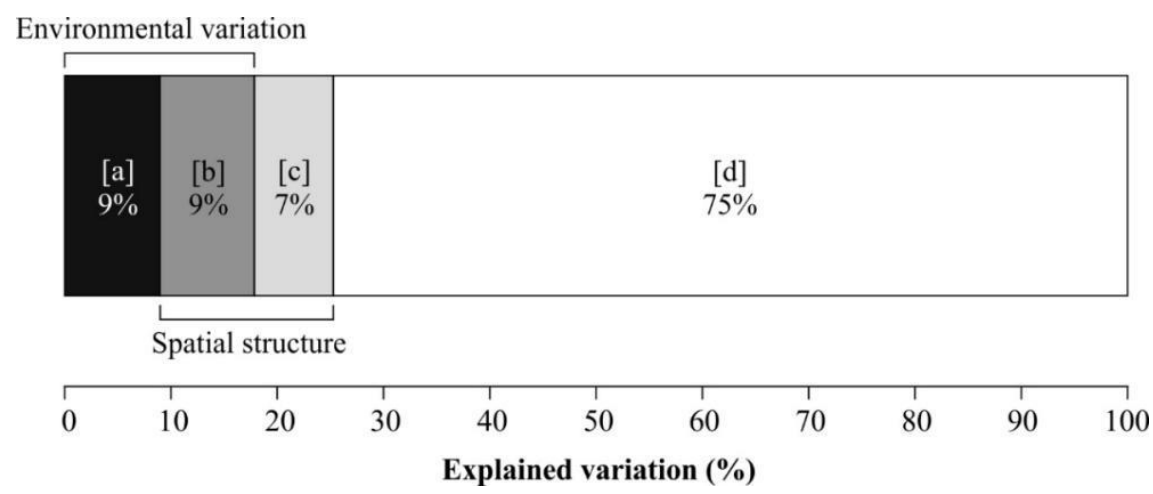

Figure 4. Partition of the variance by the redundancy analysis to determine the fractions "pure" environment [a], space + environment [b], "pure" space [c] and undetermined variables [d] for the Araucaria forest regeneration in Southern Brazil

\section{Discussion}

Our results indicate that some of the quantified environmental variables influence the distribution of the regenerating species of the Araucaria Forest in the South of Brazil. They also indicate that the spatial structure, generally neglected in studies on subtropical forest regeneration, plays an important role in forest regeneration. The spatial structure is less relevant to environmental variables but influences the distribution of some species. Among the factors that influenced the distribution of regenerating species the most in the Araucaria Forest is the variation related to the canopy opening. Studies related to the distribution of species have shown that the luminosity variation within the forest influences the species distribution (Duarte et al., 2002; Higuchi et al., 2015). The canopy opening and the variation of luminosity are related to climatic events (e.g., storm) that occurred prior to the development of the present study, and may be influencing the distribution of the species. Biotic/stochastic events may alter light input into the forest, affecting the dynamics of regeneration within tropical forests (Peixoto et al., 2012; Horn et al., 2015; Kersten et al., 2015).

We verified high density of regenerating individuals of Allophylus edulis in plots with greater canopy opening, indicating that this species frequently occurs in open areas such as forest edges or natural clearings (Maçaneiro et al., 2016b). The luminosity is one of the main factors that affect the establishment and growth of plants, being fundamental in the structure of the forests (Duarte et al., 2002). In our study, we verified different levels of luminosity within the forest, associated to stochastic factors and/or possibly to successional processes. These conditions reflect in the existence of different environments within the forest, which are explored by groups of species with different survival abilities (Baldeck et al., 2013). Thus, the differences in floristic composition 
and density of the species correspond mainly to the intensity of the canopy opening within the forest.

Considering the influence of environmental variables on forest regeneration, we observed that the soil $\mathrm{Ca} / \mathrm{K}$ content positively influences the distribution of some species (e.g., Nectandra megapotamica, Rudgea parquioides). Soil fertility, for example, is usually associated with some chemical element present in a greater or lesser quantity, varying in relation to local soil characteristics, depth and texture, among others. Studies have shown a strong relationship between soil characteristics and floristic composition, generally associated with $\mathrm{pH}$, texture and moisture content (Dubuis et al., 2012; Mélo et al., 2013), differently from what we observed in this study. The presence of $\mathrm{Ca} / \mathrm{K}$ in the soil may influence the distribution process of the species because they are elements associated with germination, growth and resistance at low temperatures. In our study, the environmental variables (represented by the canopy opening and the presence of $\mathrm{Ca} / \mathrm{K}$ ) were not the only processes that explained the species distribution.

The spatial component may be associated with biotic/stochastic processes (e.g., dispersion, facilitation, competition, pollination and predation) (Lewis et al., 2014), which in this study revealed a significant fraction of the floristic patterns. Among the stochastic processes that can influence the spatial distribution, dispersion plays a fundamental role in the colonization of regenerating species and is influenced by several external components (e.g., animals, wind) (Wang and Smith 2002; Urbanetz et al., 2003; Neuschulz et al., 2016). The facilitacion and competition processes can also influence the spatial distribution of species, but these processes do not depend on the physical factors of the environment and may occur in different climatic conditions (Mélo et al., 2013). In this case, we observed that climatic events and stochastic process may be influencing the species distribution and are playing a role in the colonization of certain species in regeneration. Environments that present adversities can act like an ecological filter, in order to affect the performance of some species (Temperton and Hobbs, 2004; Gotelli, 2007). Likewise, the maintenance and establishment of regeneration in the study area may be occurring through the processes of pollination and seed predation (Wang and Smith, 2002). Therefore, to determine these ecological patterns it is necessary to replicate the study to create forest patterns (Scipioni et al., 2009).

In the present study, the partitioning of the data set variance indicated that the highest percentage of factors that interfered in distribution patterns is related to unknown fractions (75\%). According to Lewis et al. (2014), variation of species composition along the plots and heterogeneity are factors that increase the unknown fractions. In addition, the environmental variables used are not necessarily the predictors that best explain the species distribution variations (Soininen, 2014). Another reason is the weakening of environmental responses when using the variance partition (Angeler et al., 2013). Likewise, it revealed that "pure" environment factors (9\%) and "pure" space (7\%) were statistically significant, being important predictors to explain the distribution of regenerating species in the Araucaria Forest in Southern Brazil. In this way, it is crucial to carry out new studies, which aim to include observations on dispersion, pollination and competition patterns, among others, to respond unknown factors (DinizFilho et al., 2012; Peña-Claros et al., 2012). 


\section{Conclusion}

Although much floristic variation remained unexplained, the results indicated the complex effect of environmental and spatial variables on the regeneration patterns of the Araucaria Forest in Southern Brazil. The environmental variable with the greatest influence on the distribution of the natural regeneration of the Araucaria Forest was the opening of the canopy. This variable affected certain species of the regenerating component. In addition to this variable, the soil $\mathrm{Ca} / \mathrm{K}$ content influenced certain species, but it was not as fundamental as the canopy opening. Despite the environmental influence on the species distribution, it is important to emphasize the importance of the spatial structure on the forest regeneration, being this one of the variables that influenced the vegetation the most. In the same sense, the spatial components generally neglected in ecological studies have shown great influence in the distribution and must be taken into consideration to analyze forest environments.

Considering that the study was developed at a local scale, other works should be developed to determine the floristic pattern for the Araucaria Forest. It is important to investigate further the association between species and environmental standards and to analyze the influence of different spatial variables such as competition, dispersion, microclimate, among other variables not presented in this study, since the addition of these variables may increase the predictive power of floristic patterns in subtropical forests.

Acknowledgements. The authors are grateful to Coordenação de Aperfeiçoamento de Pessoal de Nível Superior (CAPES) and Conselho Nacional de Desenvolvimento Cientifico e Tecnológico (CNPq) for their research fellowship grant (141232/2018-8). We also thank Marta Helena Cúrio de Caetano from FURB Idiomas for English review.

\section{REFERENCES}

[1] Alvares, C. A., Stape, J. L., Sentelhas, P. C., Gonçalves, J. L. M., Sparovek, G. (2013): Köppen's climate classification map for Brazil. - Meteorologische Zeitschrift 22(6): 711728.

[2] Angeler, D. G., Göthe, E., Johnson, R. K. (2013): Hierarchical dynamics of ecological communities: do scales of space and time match? - PLoS One 8(7): e69174.

[3] APG IV. (2016): An update of the Angiosperm Phylogeny Group classification for the orders and families of flowering plants: APG IV. - Botanical Journal of the Linnean Society 181(1): 1-20.

[4] Baldeck, C. A., Harms, K. E., Yavitt, J. B., John, R., Turner, B. L., Valencia, R., Navarrete, H., Davies, S. J., Chuyong, G. B., Kenfack, D., Thomas, D. W., Madawala, S., Gunatilleke, N., Gunatilleke, S., Bunyavejchewin, S., Kiratiprayoon, S., Yaacob, A., Supardi, M. N., Dalling, J. W. (2013): Soil resources and topography shape local tree community structure in tropical forests. - Proceedings of the Royal Society B: Biological Sciences 280(1753): 2012-2532.

[5] Borcard, D., Gillet, F., Legendre, P. (2011): Numerical Ecology with R. - Dordrecht London Heidelberg, New York.

[6] Diniz-Filho, J. A. F., Siqueira, T., Padial, A. A., Rangel, T. F., Landeira, V. L., Bini, L. M. (2012): Spatial autocorrelation analysis allows disentangling the balance between neutral and niche processes in metacommunities. - Oikos 121(2): 201-210. 
[7] Duarte, L., Dillenburg, L. R., Rosa, L. M. G. (2002): Assessing the role of light availability in the regeneration of Araucaria angustifolia (Araucariaceae). - Australian Journal of Botany 50: 741-751.

[8] Dubuis, A., Giovanettina, S., Pellissier, L., Pottier, J., Vittoz, P., Guisan, A. (2012): Improving the prediction of plant species distribution and community composition by adding edaphic to topo-climatic variables. - Journal of Vegetation Science 24(4): 593606.

[9] Gotelli, N. J. (2007): Sucessão. - In: Gotelli, N. J. (ed.) Ecologia. Editora Planta, Londrina, Brasil, 328p.

[10] Higuchi, P., Silva, A. C., Buzzi Junior, F., Negrinii, M., Ferreira, T. S., Souza, S. T., Santos, K. F., Vefago, M. B. (2015): Determinant factors on natural regeneration in a fragment of araucaria forest on Santa Catarina State plateau. - Scientia Forestalis 43(106): 251-259.

[11] Higuchi, P., Silva, A. C., Ferreira, T. S., de Souza, S. T., Gomes, J. P., da Silva, K. M. (2016): Floristic and structure of the tree component and relation with environmental variables in a forest remnant in Campos Novos-SC. - Ciência Florestal 26(1): 35-46.

[12] Horn, J., Becher, M. A., Kennedy, P. J., Osborne, J. L., Grimm, V. (2015): Multiple stressors: using the honeybee model BEEHAVE to explore how spatial and temporal forage stress affects colony resilience. - Oikos 125(7): 1001-1016.

[13] IBGE. (2012): Manual Técnico da Vegetação Brasileira. - Rio de Janeiro, Instituto Brasileiro de Geografia e Estatística, Brazil.

[14] Kersten, R. A., Borgo, M., Galvão, F. (2015): Floresta Ombrófila Mista: aspectos fitogeográficos, ecológicos e métodos de estudo. - In: Eisenlohr, P. V., Felfili, J. M., Melo, M. M. R. F., Andrade, L. A., Meira Neto, J. A. A. (eds.) Fitossociologia no Brasil: métodos e estudos de casos. UFV, Viçosa, Brasil.

[15] Legendre, P., Legendre, L. (2012): Numerical ecology. - Elsevier, Amsterdam, Netherlands.

[16] Lewis, R. J., Pakeman, R. J., Marrs, R. H. (2014): Identifying the multi-scale spatial structure of plant community determinants of an important national resource. - Journal of Vegetation Science 25(1): 184-197.

[17] Loebens, R., da Silva, A. C., Higuchi, P., Mafra, A. L., da Silva, J. O., Gonçalves, D. A., Souza, K., Cruz, A. P., Rodrigues Jr., L. C., Dalla Rosa, A.., Lima, C. L., Buzzi Jr., F. (2018): Partitioning of floristic-structural variation of the tree component in an alluvial Araucaria Forest in Southern Brazil. - Ciência Florestal 28(2): 554-566.

[18] Maçaneiro, J. P., Oliveira, L. Z., Seubert, R. C., Eisenlohr, P. V., Schorn, L. A. (2016a): More than environmental control at local scales: do spatial processes play an important role on floristic variations in Subtropical Forests? - Acta Botanica Brasilica 30(2): 183192.

[19] Maçaneiro, J. P., Seubert, R. C., Heilmann, A., Schorn, L. A. (2016b): Regeneration of a Mixed Ombrophilous Forest on the Santa Catarina Plateau. - Biotemas 29(4): 31-42.

[20] Maçaneiro, J. P., Gasper, A. L., Galvão, F., Schorn, L. A. (2018): Dispersion and aggregation patterns of tree species in Araucaria Forest, Southern Brazil. - Anais da Academia Brasileira de Ciências 90(2 Suppl. 1): 2397-2408.

[21] Maçaneiro, J. P., Liebsch, D., Gasper, A. L., Galvão, F., Schorn, L. A. (2019): Structural and floristic variations in an Atlantic Subtropical Rainforest in Southern Brazil. - Floresta e Ambiente 26(1): e20160101.

[22] McCune, B., Mefford, M. J. (2011): PC-ORD: Multivariate analysis of ecological data, Version 6. - MjM Software Design. Gleneden Beach, Oregon.

[23] Mélo, M. A., Budke, J. C., Henke-Oliveira, C. (2013): Relationships between structure of the tree component and environmental variables in a subtropical seasonal forest in the upper Uruguay River valley, Brazil. - Acta Botanica Brasilica 27(4): 751-760. 
[24] Neuschulz, E. L., Mueller, T., Schleuning, M., Böhning-Gaese, K. (2016): Pollination and seed dispersal are the most threatened processes of plant regeneration. - Scientific Reports 6(29839): 1-6.

[25] Oliveira-Filho, A. T. (2015): Um sistema de classificação fisionômico-ecológico da vegetação neotropical: segunda aproximação. - In: Eisenlohr, P. V., Felfili, J. M., Melo, M. M. F., Andrade, L. A., Meira-Neto, J. A. A. (eds.) Fitossociologia no Brasil: métodos e estudos de caso. Viçosa: Editora UFV.

[26] Peixoto, K. S., Sanchez, M., Pedroni, F., Ribeiro, M. N., Facure, K. G., Klein, V. L. G. (2012): Dinâmica da comunidade arbórea em uma floresta estacional semidecidual sob queimadas recorrentes. - Acta Botanica Brasílica 26(3): 697-708.

[27] Peña-Claros, M., Poorter, L., Alarcon, A., Blate, G., Choque, U., Fredericksen, T. S., Justiniano, M. J., Leano, C., Licona, J. C., Pariona, W., Putz, F. E., Quevedo, L., Toledo, M. (2012): Soil effects on forest structure and diversity in a moist and a dry Tropical Forest. - Biotropica 44(3): 276-283.

[28] Pinagé, E. R., Gomes, A. R, Osako, L. S., Matricardi, E. A. T., Guimarães, U. S., Santos, A. H. H. (2013): Estimativa da fração de cobertura florestal em áreas de manejo florestal com a utilização do analisador ótico LAI-2000 e fotografias hemisféricas. - In: XVI Simpósio brasileiro de Sensoriamento Remoto, pp. 2944-2951.

[29] PPG I. (2016): A community-derived classification for extant lycophytes and ferns. Journal of Systematics and Evolution 54(6): 563-603.

[30] Ribeiro, M. C., Martensen, A. C., Metzger, J. P., Tabarelli, M., Scarano, F., Fortin, M. J. (2011): The Brazilian Atlantic forest: a shrinking biodiversity hotspot. - In: Zachos, F. E., Habel, J. C. (eds.) Biodiversity hotspots. Springer, Heidelberg.

[31] Rocha, R. P., Silva, M. B. (2013): História Biogeográfica da Mata Atlântica: Opiliões (Arachnida) como modelo para sua inferência. - In: Carvalho, C. J. B., Almeida, E. A. B. (eds.) Biogeografia da América do Sul: Padrões e processos. Roca, São Paulo, Brasil.

[32] Santa Catarina. (1986): Atlas de Santa Catarina. - GAPLAN/SUEGI, Florianópolis.

[33] Santos, H. G., Jacomine, P. K. T., Anjos, L. H. C., Oliveira, V. A. V., Lumbreras, J. F., Coelho, M. R., Almeida, J. A., Cunha, T. J. F., Oliveira, J. B. (2018): Sistema Brasileiro de Classificação de Solos. - Embrapa, Distrito Federal.

[34] Scipioni, M. C., Longhi, S. J., Araújo, M. M., Reinert, D. J. (2009): Regeneração natural de um fragmento da Floresta Estacional Decidual na Reserva Biológica do Ibicuí-Mirim (RS). - Floresta 39(1): 675-690.

[35] Soininen, J. A. (2014): A quantitative analysis of species sorting across organisms and ecosystems. - Ecology 95(12): 3284-3292.

[36] Souza, C. C., Higuchi, P., Silva, A. C., Souza, K., Rosa, A. D., Rech, C. C. C., Rodrigues Júnior, L. C., Walter, F. F. (2017): Floristic-structural variation of natural regeneration along different topographic positions of an ecotonal forest in Santa Catarina, Brazil. Revista Árvore 41(3): e410305.

[37] Suganuma, S. M., Torezan, J. M. D., Cavalheiro, A. L., Vanzela, A. L. L., Benato, T. (2008): Comparando metodologias para avaliar a cobertura do dossel e a luminosidade no sub-bosque de um reflorestamento e uma floresta madura. - Revista Árvore 32(2): 377 385 .

[38] Teixeira, P. C., Donagemma, G. K., Fontana, A., Teixeira, W. G. (2017): Manual de métodos de análise de solo. - Embrapa, Brasília.

[39] Temperton, V. M., Hobbs, R. J. (2004): The search for ecological assembly rules and its relevance to restoration ecology. - In: Temperton, V. M., Hobbs, R. J., Nuttle, T., Halle, S. (eds.) Assembly rules and restoration ecology: brindging the gap between theory and practice. Island Press, New York.

[40] Urbanetz, C., Oliveira, V. M., Raimundo, R. L. G. (2003): Padrão espacial, escala e síndromes de dispersão. - Relatório Unicamp.

[41] Wang, B. C., Smith, T. B. (2002): Closing the seed dispersal loop. - Trends in Ecology and Evolution 17(8): 379-386. 
[42] Weiss, M., Baret, F. (2010): Venus biophysical variable products algorithm theoretical basis document. - EMMAH, INRA.

\section{APPENDIX}

Appendix 1. Floristic field data for the Araucaria forest regeneration in Southern Brazil

\begin{tabular}{|c|c|c|c|c|c|c|}
\hline Family & $\begin{array}{l}\text { Species } \\
\end{array}$ & $\mathbf{n}$ & $D A$ & $D R$ & $F A$ & $F R$ \\
\hline Annonaceae & Annona emarginata (Schltdl.) H.Rainer & 19 & 484 & 4.1 & 25.0 & 2,9 \\
\hline Araucariaceae & Araucaria angustifolia (Bertol.) Kuntze & 13 & 331 & 2.8 & 35.0 & 4,1 \\
\hline \multirow[t]{2}{*}{ Asteraceae } & Baccharis dentata (Vell.) G.M.Barroso & 3 & 76 & 0.6 & 5.0 & 0,6 \\
\hline & Piptocarpha angustifolia Dusén ex Malme & 1 & 25 & 0.2 & 5.0 & 0,6 \\
\hline Canellaceae & Cinnamodendron dinisii Schwacke & 15 & 382 & 3.2 & 35.0 & 4,1 \\
\hline Celastraceae & Schaefferia argentinensis Speg. & 1 & 25 & 0.2 & 5.0 & 0,6 \\
\hline \multirow[t]{3}{*}{ Euphorbiaceae } & Bernardia pulchella (Baill.) Müll.Arg. & 2 & 51 & 0.4 & 5.0 & 0,6 \\
\hline & Sebastiania brasiliensis Spreng. & 27 & 688 & 5.8 & 25.0 & 2,9 \\
\hline & Gymnanthes klotzschiana Müll.Arg. & 3 & 76 & 0.6 & 15.0 & 1,8 \\
\hline Fabaceae & $\begin{array}{c}\text { Muellera campestris (Mart. ex Benth.) M.J. Silva \& } \\
\text { A.M.G. Azevedo }\end{array}$ & 2 & 51 & 0.4 & 5.0 & 0,6 \\
\hline \multirow[t]{7}{*}{ Lauraceae } & Cinnaтотит атоепит (Nees \& Mart.) Kosterm. & 1 & 25 & 0.2 & 5.0 & 0,6 \\
\hline & Nectandra lanceolata Nees & 2 & 51 & 0.4 & 5.0 & 0,6 \\
\hline & Nectandra megapotamica (Spreng.) Mez & 6 & 153 & 1.3 & 20.0 & 2,3 \\
\hline & Ocotea puberula (Rich.) Nees & 1 & 25 & 0.2 & 5.0 & 0,6 \\
\hline & Ocotea pulchella (Nees \& Mart.) Mez & 1 & 25 & 0.2 & 5.0 & 0,6 \\
\hline & Ocotea pulchra Vattimo-Gil & 4 & 102 & 0.9 & 15.0 & 1,8 \\
\hline & Ocotea sp. Aubl. & 2 & 51 & 0.4 & 10.0 & 1,2 \\
\hline Loganiaceae & Strychnos brasiliensis Mart. & 1 & 25 & 0.2 & 5.0 & 0,6 \\
\hline \multirow[t]{2}{*}{ Malvaceae } & Luehea divaricata Mart. \& Zucc. & 3 & 76 & 0.6 & 15.0 & 1,8 \\
\hline & Pavonia sepium A.St.-Hil. & 6 & 153 & 1.3 & 10.0 & 1,2 \\
\hline Melastomataceae & Miconia cinerascens Miq. & 20 & 509 & 4.3 & 10.0 & 1,2 \\
\hline Meliaceae & Trichilia elegans A.Juss. & 1 & 25 & 0.2 & 5.0 & 0,6 \\
\hline \multirow[t]{8}{*}{ Myrtaceae } & Campomanesia guaviroba (DC.) Kiaersk. & 4 & 102 & 0.9 & 10.0 & 1,2 \\
\hline & Eugenia rostrifolia D.Legrand & 1 & 25 & 0.2 & 5.0 & 0,6 \\
\hline & Eugenia sp. L. & 29 & 738 & 6.2 & 40.0 & 4,7 \\
\hline & Eugenia uniflora $\mathrm{L}$. & 12 & 306 & 2.6 & 30.0 & 3,5 \\
\hline & Myrceugenia mesomischa (Burret) D.Legrand \& Kausel & 1 & 25 & 0.2 & 5.0 & 0,6 \\
\hline & Myrcia glabra (O.Berg) D.Legrand & 1 & 25 & 0.2 & 5.0 & 0,6 \\
\hline & Myrcia hartwegiana (O.Berg) Kiaersk. & 1 & 25 & 0.2 & 5.0 & 0,6 \\
\hline & Pimenta pseudocaryophyllus (Gomes) Landrum & 2 & 51 & 0.4 & 5.0 & 0,6 \\
\hline Oleaceae & **Ligustrum lucidum W.T.Aiton & 1 & 25 & 0.2 & 5.0 & 0,6 \\
\hline Podocarpaceae & Podocarpus lambertii Klotzsch ex Endl. & 4 & 102 & 0.9 & 10.0 & 1,2 \\
\hline \multirow[t]{3}{*}{ Primulaceae } & Myrsine coriacea (Sw.) R.Br. ex Roem. \& Schult. & 1 & 25 & 0.2 & 5.0 & 0,6 \\
\hline & Myrsine parvula $(\mathrm{Mez})$ Otegui & 2 & 51 & 0.4 & 5.0 & 0,6 \\
\hline & Myrsine umbellata Mart. & 47 & 1197 & 10.1 & 55.0 & 6,4 \\
\hline Proteaceae & Roupala montana Aubl. & 2 & 51 & 0.4 & 10.0 & 1,2 \\
\hline Rubiaceae & Rudgea parquioides (Cham.) Müll.Arg. & 14 & 357 & 3.0 & 30.0 & 3,5 \\
\hline \multirow[t]{2}{*}{ Rutaceae } & Zanthoxylum kleinii (R.S.Cowan) P.G.Waterman & 3 & 76 & 0.6 & 10.0 & 1,2 \\
\hline & Zanthoxylum rhoifolium Lam. & 1 & 25 & 0.2 & 5.0 & 0,6 \\
\hline \multirow[t]{2}{*}{ Salicaceae } & Casearia decandra Jacq. & 36 & 917 & 7.7 & 45.0 & 5,3 \\
\hline & Casearia obliqua Spreng. & 1 & 25 & 0.2 & 5.0 & 0,6 \\
\hline \multirow[t]{4}{*}{ Sapindaceae } & Allophylus edulis (A.St.-Hil. et al.) Hieron. ex Niederl. & 68 & 1732 & 14.6 & 65.0 & 7,6 \\
\hline & Allophylus guaraniticus (A. St.-Hil.) Radlk. & 25 & 637 & 5.4 & 40.0 & 4,7 \\
\hline & Cupania vernalis Cambess. & 3 & 76 & 0.6 & 10.0 & 1,2 \\
\hline & Matayba elaeagnoides Radlk. & 31 & 789 & 6.7 & 60.0 & 7,0 \\
\hline \multirow[t]{2}{*}{ Solanaceae } & Brunfelsia cuneifolia J.A.Schmidt & 3 & 76 & 0.6 & 10.0 & 1,2 \\
\hline & Brunfelsia pilosa Plowman & 9 & 229 & 1.9 & 20.0 & 2,3 \\
\hline Styracaceae & Styrax leprosus Hook. \& Arn. & 10 & 255 & 2.1 & 25.0 & 2,9 \\
\hline Thymelaeaceae & Daphnopsis racemosa Griseb. & 1 & 25 & 0.2 & 5.0 & 0,6 \\
\hline Winteraceae & Drimys brasiliensis Miers & 1 & 25 & 0.2 & 5.0 & 0,6 \\
\hline
\end{tabular}




\begin{tabular}{c|c|c|c|c|c|c}
- & NI 01 & 3 & 76 & 0.6 & 10.0 & 1,2 \\
- & NI 02 & 4 & 102 & 0.9 & 10.0 & 1,2 \\
- & NI 03 & 2 & 51 & 0.4 & 5.0 & 0,6 \\
- & NI 04 & 1 & 25 & 0.2 & 5.0 & 0,6 \\
- & NI 05 & 1 & 25 & 0.2 & 5.0 & 0,6 \\
- & NI 06 & 3 & 76 & 0.6 & 5.0 & 0,6 \\
- & NI 07 & 1 & 25 & 0.2 & 5.0 & 0,6 \\
- & NI 08 & 2 & 51 & 0.4 & 5.0 & 0,6 \\
- & NI 09 & 1 & 25 & 0.2 & 5.0 & 0,6 \\
\hline
\end{tabular}

$* *$ = alien species, $\mathrm{DA}=$ absolute density $\left(\mathrm{ind}^{-h^{-1}}\right), \mathrm{DR}=$ relative density $(\%), \mathrm{FA}=$ absolute frequency $(\%), \mathrm{FR}=$ relative frequency $(\%)$

Appendix 2. Environmental average field data for the Araucaria forest regeneration in Southern Brazil

\begin{tabular}{|c|c|c|c|}
\hline Environmental data & Average $(n=20)$ & Variance & SD \\
\hline Elevation $(\mathrm{m})$ & 897 & 3712 & 61 \\
\hline Clay $(\%)$ & 36.95 & 81.00 & 9.00 \\
\hline $\mathrm{pH}$ & 4.37 & 0.43 & 0.66 \\
\hline SMP (\%) & 4.89 & 0.52 & 0.72 \\
\hline $\mathrm{K}\left(\mathrm{mg} / \mathrm{dm}^{3}\right)$ & 151.00 & $3,242.32$ & 56.94 \\
\hline $\mathrm{Al}$ (cmolc/d) & 2.64 & 3.74 & 1.93 \\
\hline $\mathrm{Ca}(\mathrm{cmolc} / \mathrm{d})$ & 6.01 & 41.56 & 6.45 \\
\hline $\mathrm{Mg}(\mathrm{cmolc} / \mathrm{dm})$ & 1.50 & 3.10 & 1.76 \\
\hline $\mathrm{H}+\mathrm{Al}\left(\mathrm{cmolc} / \mathrm{dm}^{3}\right)$ & 20.17 & 136.20 & 11.67 \\
\hline $\mathrm{CTCpH}\left(\mathrm{cmolc} / \mathrm{dm}^{2}\right)$ & 28.06 & 59.96 & 7.74 \\
\hline $\mathrm{Na}$ CTC-Al (\%) & 37.40 & 781.20 & 27.95 \\
\hline Sat CTC-V (\%) & 31.13 & 942.13 & 30.69 \\
\hline Sum of bases (\%) & 7.89 & 64.65 & 8.04 \\
\hline $\mathrm{Ca} / \mathrm{K}$ & 13.68 & 147.97 & 12.16 \\
\hline $\mathrm{Mg} / \mathrm{K}$ & 3.58 & 16.44 & 4.06 \\
\hline Humidity (\%) & 49.0 & 329.30 & 18.15 \\
\hline Canopy opening (\%) & 17.9 & 34.76 & 5.90 \\
\hline Leaf area $\left(\mathrm{m}^{2}\right)$ & 5.00 & 0.47 & 0.69 \\
\hline Luminosity (\%) & 0.86 & 0.002 & 0.04 \\
\hline
\end{tabular}

